\title{
Vertical distribution of number, biomass and size-class spectrum of bacteria in relation to oxic/anoxic conditions in the Central Baltic Sea
}

\author{
Veronika Gast, Klaus Gocke
}

Institut für Meereskunde an der Universität Kiel, Düsternbrooker Weg 20, D-2300 Kiel, Federal Republic of Germany

\begin{abstract}
Total bacterial numbers and bacterial biomass were determined, and the size-class spectrum analysed, of the bacterial population in the Gotland Basin (Central Baltic Sea) during pronounced cyanobacterial blooms. Numbers of aerobic and anaerobic saprophytic bacteria and of sulphate-reducers are also reported. Below the oxic-anoxic interface a morphological change in the microfloral populations was observed. The size-class spectrum in anoxic bottom waters shifted towards larger cell forms. Average cell volume increased about 3 -fold over that found in oxic waters. Anaerobic saprophytes and sulphate-reducers became more important in the $\mathrm{H}_{2} \mathrm{~S}$-rich bottom waters. Anaerobic micro-environments in $\mathrm{O}_{2}$-saturated water layers are discussed as important microbiotopes for anaerobic bacteria (e.g. sulphate-reducers).
\end{abstract}

\section{INTRODUCTION}

The lack of water circulation in stratified water bodies (with a thermocline and halocline) in conjunction with continuous $\mathrm{O}_{2}$-consumption by remineralization leads eventually to complete $\mathrm{O}_{2}$ depletion. First nitrate, and then sulphate is used for the degradation of organic materials in anoxic water. As a result, $\mathrm{H}_{2} \mathrm{~S}$ is then produced by dissimilatory reduction of sulphate by sulphate-reducing bacteria.

Deep anoxic water occurs especially in the deeper basins of the Baltic Sea, such as the Farö Basin, Gotland Basin, Landsort Basin, Karlsö Basin and Bornholm Basin (Fonselius 1981). However, it also occurs under specific hydrographic conditions as a transitional event in shallow water areas such as the eastern Belt Sea, the Lübeck and Eckernförde Bights, and in the Baltic Sea fjords, such as the Flensburg and Kiel Fjords (Ehrhardt \& Wenck 1984)

Despite the great importance of bacteria in formation of anoxic environments, comparatively little microbiological information on this phenomenon is available from the Baltic Sea. Past studies have concentrated on the role of bacteria in anoxic sediments (Jørgensen 1978, Laanbroek \& Pfennig 1981, Jørgensen 1982, Widdel \& Pfennig 1982, Meyer-Reil 1983). Bacterial sulphate reduction in water has been studied in the fjords (Kiel and Schlei Fjords) and in the Kiel Bight (Bansemir \& Rheinheimer 1970, 1974, Schneider 1977). Seppänen \& Voipio (1971) found a correlation between bacteriological and physico-chemical parameters in the Gotland Basin.

This investigation focuses on a more detailed analysis of the adaptation of heterotrophic microorganisms to changes from aerobic to anaerobic conditions. Changes within the bacterial population were observed through total bacterial counts, bacterial biomass, and the sizeclass spectrum. Aerobic and anaerobic saprophytic bacteria as well as obligate anaerobic sulphate-reducers were also monitored.

\section{MATERIALS AND METHODS}

Study site and sampling. The Gotland Basin is a depression in the Central Baltic Sea with special hydrographical characteristics. Exchange of $\mathrm{O}_{2}$-rich surface water with bottom water is greatly restricted by a permanent halocline and a thermocline which forms during summer. Sinking organic matter produced in the euphotic zone is further degraded beneath the halocline, causing a decrease in the $\mathrm{O}_{2}$-concentration, and leading eventually to complete anoxia. Thus $\mathrm{H}_{2} \mathrm{~S}$ containing water is formed in the deeper layers. Stag- 
nation periods lasting several years with anaerobic bottom water are occasionally interrupted when highdensity $\mathrm{O}_{2}$-rich water flows through the Belt into the Gotland Basin from the North Sea (Fonselius 1981).

Several microbiological techniques were tested in August 1983 during a joint cruise aboard FS 'Poseidon', and first samples taken at 'Hanglage' $\left(57^{\circ} 16.5^{\prime} \mathrm{N}\right.$, $19^{\circ} 44.7^{\prime} E_{i}$ Fig. 1). A further excursion was undertaken in August 1984 on FK 'Alkor' to the Gotland Basin ('Central' station, $57^{\circ} 20^{\prime} \mathrm{N}, 20^{\circ} 04^{\prime} \mathrm{E}$ ). 'Hanglage' and 'Central' station differed in their total water depths (195 and $243 \mathrm{~m}$ respectively), and the position of the $\mathrm{O}_{2} / \mathrm{H}_{2} \mathrm{~S}$ boundary layer (130 and $145 \mathrm{~m}$ respectively). Hydrographical and chemical parameters were otherwise similar. An anchor station, installed in August 1984, provided detailed information on the vertical distribution of physico-chemical and microbiological parameters with special emphasis on the euphotic zone, the interface between oxic and anoxic water, and the nearbottom water layer.

Water samples for chemical investigations were obtained with Niskin bottles; samples for bacteriological investigations were taken with ZoBell samplers down to $120 \mathrm{~m}$ and with sterile bag samplers below that depth. Near-bottom water samples at $25 \mathrm{~cm}, 1 \mathrm{~m}$, and $2 \mathrm{~m}$ above the sea floor were collected with a specially designed bottom-water sampler.

Hydrographical and chemical parameters. Temperature and salinity profiles were obtained with the aid of

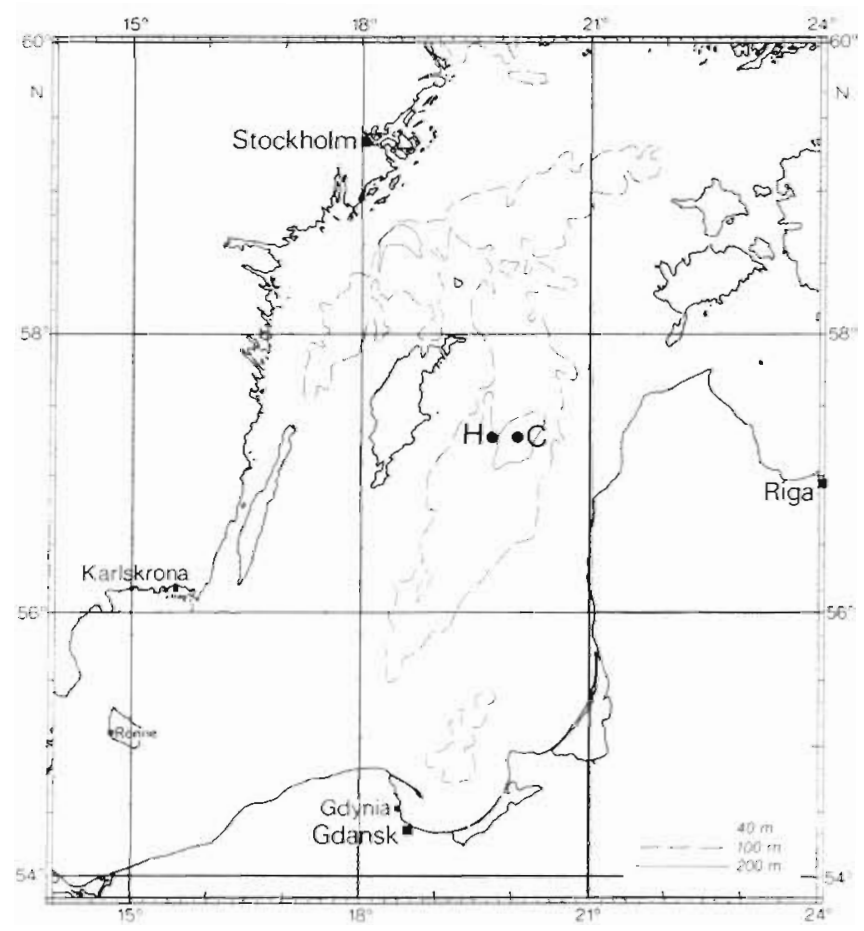

Fig. 1. Location of sampling stations in the Gotland Deep, Baltic Sea. C: 'Central' station; H: 'Hanglage' station a 'Multisonde Kiel' from the firm ME (Trappenkamp, FR Germany). $\mathrm{O}_{2}$-determinations were performed using a modification of the Winkler method (Grasshoff 1976). $\mathrm{H}_{2} \mathrm{~S}$ was measured photometrically according to Fonselius (1976). Nitrate and ammonia were estimated using the method described by Grasshoff $(1964,1968)$.

Bacteriological parameters. Total bacterial number (TBN) was estimated, after staining the cells with acridine orange, by epifluorescence microscopy according to Zimmermann et al. (1978). It was necessary to measure bacterial cells individually in order to calculate bacterial biomass (BBM) because of the strong variation in size-class spectra of bacteria populations from different water samples. Color slides from the fluorescence microscopic preparations were made and examined with a semi-automatic image analyzer (MOP AM-02; Kontron). Practical implementation and calculation of biomass were based on the procedure of Meyer-Reil (1983).

The following medium was used to determine both aerobic and anaerobic saprophytic bacteria: $5 \mathrm{~g}$ peptone, $1 \mathrm{~g}$ yeast extract, $0.3 \mathrm{~g}$ sodium thioglycolate, $1 \mathrm{ml}$ $0.1 \%$ Resazurin solution, and $15 \mathrm{~g}$ agar to $1 \mathrm{l}$ brackish water (salinity $8 \%$ ) at $\mathrm{pH} 7.4$. The medium was autoclaved for $20 \mathrm{~min}$ at $121^{\circ} \mathrm{C}$. Six agar plates per sample were inoculated with $0.2 \mathrm{ml}$ water using the spread plate method. Of these 3 were incubated aerobically, and 3 anaerobically. Colonies were counted after 2 or $3 \mathrm{wk}$.

Specially designed anaerobic incubators, each with a capacity for 60 Petri dishes, were supplied with $4 \mathrm{BBL}$ gas $\left(\mathrm{H}_{2} / \mathrm{CO}_{2}\right)$ generator envelopes (Gas Pak 70304), $36 \mathrm{~g}$ palladium catalyzer (Gas Pak 70303) in a wire box and methylene-blue strips (Gas Pak 70504). The strips served to monitor the anaerobic conditions. The incubators can be seen to be working if, ca $15 \mathrm{~min}$ after closing, water condenses due to the $\mathrm{H}_{2} / \mathrm{O}_{2}$ reaction. The methylene-blue strips (after 4 to $6 \mathrm{~h}$ ) and the nutrient medium (after 24 to $48 \mathrm{~h}$ ) become colorless and remain so until the end of incubation.

It should be stated here that the term 'aerobic saprophytes' as used in this paper includes both obligate and facultative aerobic (the latter are usually called facultative anaerobic) bacteria, and anaerobic saprophytes' likewise includes both obligate and facultative anaerobic bacteria.

Since processing the water samples required about $1 \mathrm{~h}$, during which the bacteria were in contact with oxygen, it was feared that the obligate and even the facultative anaerobic microorganisms might be affected. Therefore control tests with an obligate anaerobic bacteria species (Clostridium sporogenes) and 3 non-identified facultative anaerobic strains from the Kiel Fjord were performed. It was found that when the anaerobically precultured strains were exposed for about $1 \frac{1}{2} \mathrm{~h}$ to air, the number of anaerobically grown 
colonies was similar to the bacterial number initially present (counted by fluorescence microscopy).

The number of sulphate-reducers was estimated by the most probable number (MPN) method, using a lactate medium as both electron donor and carbon source (see Pfennig et al. 1981 and literature cited therein). The nutrient medium was composed of the following: $0.5 \mathrm{~g}$ $\mathrm{K}_{2} \mathrm{HPO}_{4}, 1.0 \mathrm{~g} \mathrm{NH}_{4} \mathrm{Cl}, 1.0 \mathrm{~g} \mathrm{Na}_{2} \mathrm{SO}_{4}, 0.1 \mathrm{~g} \mathrm{CaCl} \cdot 2 \mathrm{H}_{2} \mathrm{O}$, $2.0 \mathrm{~g} \mathrm{MgSO}_{4} \cdot 7 \mathrm{H}_{2} \mathrm{O}, 3.5 \mathrm{~g} \mathrm{Na}$-lactate (70\%), $1.0 \mathrm{~g}$ yeast extract, $0.5 \mathrm{~g} \mathrm{FeSO}_{4} \cdot 7 \mathrm{H}_{2} \mathrm{O}, 0.1 \mathrm{~g}$ ascorbic acid, $0.1 \mathrm{~g}$ Nathioglycolate, $1 \mathrm{ml}$ Resazurin solution $(0.1 \%), 8 \mathrm{~g}$ $\mathrm{NaCl}$, and $15 \mathrm{~g}$ agar to $1 \mathrm{l}$ distilled water at $\mathrm{pH}$ 7.4. The medium was autoclaved for $20 \mathrm{~min}$ at $121^{\circ} \mathrm{C}$ and then dispensed under sterile conditions as $190 \mathrm{ml}$ aliquots into $200 \mathrm{ml}$ Meplats bottles and $19 \mathrm{ml}$ aliquots into $20 \mathrm{ml}$ Sovirel tubes tightly sealed with rubber disks and closed with screw caps. The medium was again liquified on board the research vessel by boiling, cooled to about $45^{\circ} \mathrm{C}$, and then inoculated with sample water. Each of 5 Meplats bottles received $10 \mathrm{ml}$ of sample, and 5 replicate Sovirel tubes received $1 \mathrm{ml}$ of undiluted sample, $1 \mathrm{ml}$ of $1: 10,1 \mathrm{ml}$ of $1: 100$ or $1 \mathrm{ml}$ of $1: 1000$ sample, diluted with sterile brackish water ( $8 \%$ ). These were counted after a few days to $3 \mathrm{wk}$. Positive bottles or tubes contained black colonies of sulphate-reducing bacteria due to the FeS-precipitate. Counting the individual colonies often proved problematic, due to rapid obscuring of the entire medium. Estimates were thus limited to the statistical MPN method.

\section{RESULTS}

\section{Hydrographical parameters}

Calm weather during the August 1984 cruise in the Gotland Basin resulted in the formation of a pro- nounced thermocline at 15 to $20 \mathrm{~m}$ water depth (Fig, 2). Water temperature decreased from between 17.8 and $16.3^{\circ} \mathrm{C}$ above the boundary layer to $5^{\circ} \mathrm{C}$ at $20 \mathrm{~m}$ depth. The lowest temperature $\left(3.1^{\circ} \mathrm{C}\right)$ was found at $70 \mathrm{~m}$ in the so-called winter-water. Water temperature increased gradually to $5.8^{\circ} \mathrm{C}$ from $70 \mathrm{~m}$ to the seabottom. Salinity increased from $7.4 \%$ at the surface to $12.5 \%$ directly above the bottom. The halocline was situated at $70 \mathrm{~m}$.

The $\mathrm{O}_{2}$-concentration (Fig. 2) of the warmer surface water was 6.9 to $7.0 \mathrm{ml} \mathrm{O}_{2} \mathrm{l}^{-1}$ (about $110 \% \mathrm{O}_{2}$-saturation). Despite an actual increase in $\mathrm{O}_{2}$-concentration immediately below the thermocline, this water body was slightly undersaturated (95\% $\mathrm{O}_{2}$-saturation) at $30 \mathrm{~m}$ depth. Below the halocline, the $\mathrm{O}_{2}$-concentration decreased rapidly. Below approximately $145 \mathrm{~m}, \mathrm{O}_{2}$ was no longer detectable, and $\mathrm{H}_{2} \mathrm{~S}$ began to appear in increasing concentrations.

In the euphotic zone nitrate and ammonia concentrations were low due to phytoplankton activity (Fig. 2). In the cold winter-water the nitrate concentration increased significantly, but subsequently decreased to zero at the $\mathrm{O}_{2} / \mathrm{H}_{2} \mathrm{~S}$ interface. A pronounced increase in ammonia was coupled with the rapid decrease in nitrate. In the anaerobic deep water layer, the ammonia concentration hardly varied from this level.

\section{Total bacterial number and bacterial biomass}

Distribution of total bacterial number (TBN) (Figs. 3 and 4) within the oxic region of the vertical profile exhibited essentially the same pattern as found for the number of aerobic saprophytic bacteria: the population density was greatest above the thermocline (5.3 to $6.4 \times 10^{6}$ cells $\mathrm{ml}^{-1}$ ), decreased rapidly directly below the thermocline, remained at a constant low value 10.4

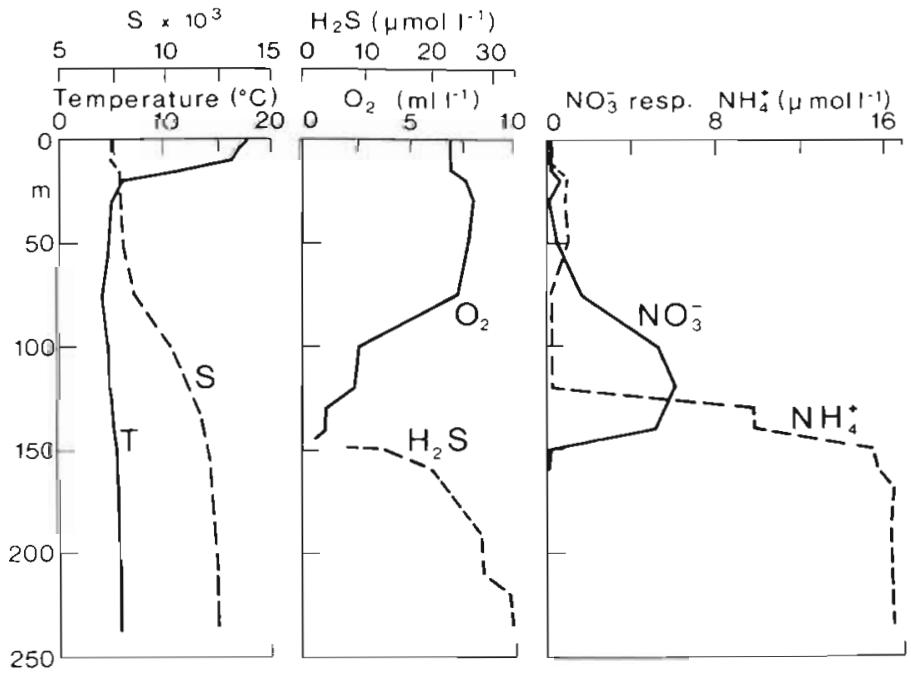

Fig. 2. Depth profiles of hydrographical and chemical parameters measured at 'Central' station on 1 Aug 


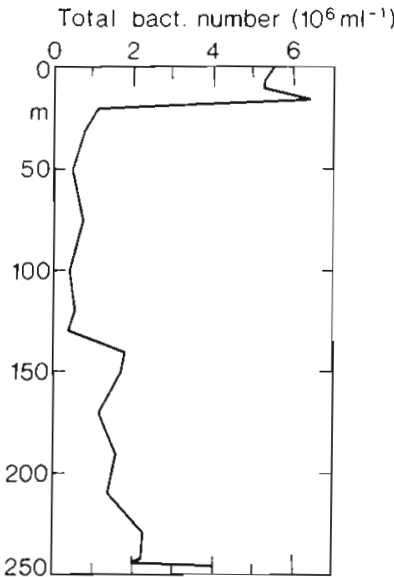

Fig. 3. Vertical distribution of total bacterial number at 'Central' station on 1 Aug 1984

to $0.8 \times 10^{6}$ cells $\left.\mathrm{mi}^{-1}\right)$ in the winter-water and finally increased again in the $\mathrm{O}_{2} / \mathrm{H}_{2} \mathrm{~S}$ interface $\left(1.2\right.$ to $1.8 \times 10^{6}$ cells $\mathrm{ml}^{-1}$ ).

TBN in anoxic regions showed a relatively small increase from 1.2 to $2.3 \times 10^{6}$ cells $\mathrm{ml}^{-1}$. Only directly above the sediment was a sudden increase up to $4.0 \times$ $10^{6}$ cells $\mathrm{ml}^{-1}$ observed. This contrasts with the number of saprophytic bacteria, which increased much more in the anoxic layers.

Detailed analysis of the bacterial biomass (BBM) was performed on the sample taken from the 'Hanglage' station in August 1983. BBM covered a range of 3 to $50 \mu \mathrm{C} \mathrm{Cl}^{-1}$ (Fig. 4). Low values were found in oxic water below the thermocline, and higher ones above the thermocline and in the anoxic water layer. In the oxic/anoxic interface, at about $130 \mathrm{~m}$ depth at this station, a morphological change within the bacterial

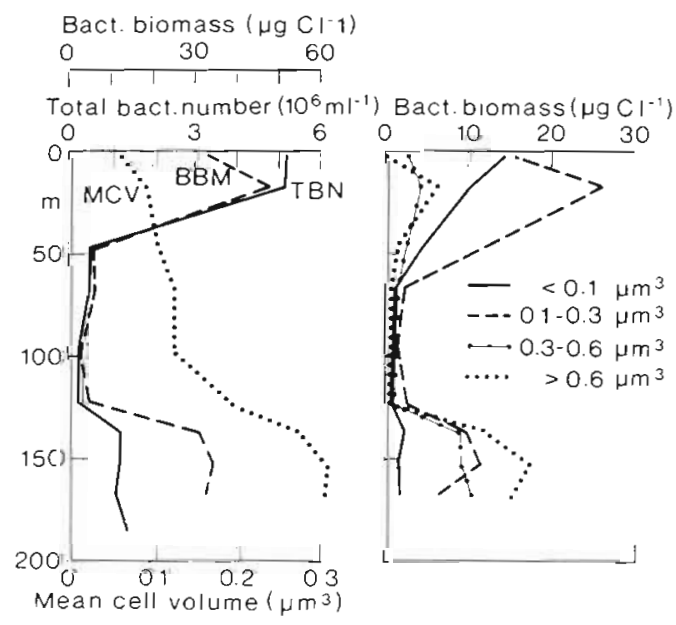

Fig. 4. Vertical distribution of (left) total bacterial number and (right) biomass of bacteria belonging to the specified size classes. 'Hanglage' station, 20 Aug 1983. TBN: total bacterial number; BBM: bacterial biomass; $\mathrm{MCV}$. mean cell volume population was observed. Small increases of bacterial numbers were coupled to comparatively large increases in BBM, because the size-class spectrum shifted towards larger cell forms. The mean cell volume, which in oxic water averaged $0.1 \mathrm{\mu m}^{3}$, doubled in the $\mathrm{O}_{2} / \mathrm{H}_{2} \mathrm{~S}$ interface, and tripled in anoxic water. The following size-classes of bacterial cells were chosen to further analyze the BBM: <0.1 $\mu^{3}, 0.1-0.3 \mu^{3}$, $0.3-0.6 \mu \mathrm{m}^{3}$ and $>0.6 \mu \mathrm{m}^{3}$. The distribution of BBM within these size classes is shown in Fig. 4. BBM in oxic water depended primarily on the $<0.1$ and $0.1-0.3 \mu \mathrm{m}^{3}$ size classes, whereas in anoxic water it depended on the $>0.6 \mu \mathrm{m}^{3}$ class with the smallest contribution being from the $<0.1 \mu^{3}$ size class.

\section{Saprophytic bacteria}

The distribution of colony-forming bacteria in the water column is shown in Fig. 5. The absolute as well as the relative number of both aerobic and anaerobic saprophytic bacteria varied within the vertical profile. Aerobic saprophytes showed distinct concentration maxima. The uppermost peak (745 saprophytes $\mathrm{ml}^{-1}$ ) corresponded with the depth of high phytoplankton production in the euphotic zone. Beneath the thermocline, aerobic saprophytic bacteria decreased rapidly in number, maintaining a constant low value (115 to 125 saprophytes $\mathrm{ml}^{-1}$ ) in cold winter-water. The second maximum, though less pronounced (270 aerobic saprophytes $\mathrm{ml}^{-1}$ ), was located directly at the $\mathrm{O}_{2} / \mathrm{H}_{2} \mathrm{~S}$ interface. With the presence of $\mathrm{H}_{2} \mathrm{~S}$ in the anoxic water layer, numbers of saprophytic bacteria decreased rapidly (25 aerobic saprophytes $\mathrm{ml}^{-1}$ ), and then increased to a near-bottom maximum of 470 aerobic saprophytes $\mathrm{ml}^{-1}$.

Anaerobic saprophytic bacteria were much less concentrated in well-aerated surface layers (up to 140 saprophytes $\mathrm{ml}^{-1}$ ) than aerobic, and exhibited great scattering. Their number remained relatively constant in cold winter-water (83 to 94 anaerobic saprophytes $\mathrm{ml}^{-1}$ ) and was always lower than the aerobic saprophyte count. Anaerobes reached a maximum, as with aerobes, at the $\mathrm{O}_{2} / \mathrm{H}_{2} \mathrm{~S}$ interface (166 anaerobic saprophytes $\mathrm{ml}^{-1}$ ). In $\mathrm{H}_{2} \mathrm{~S}$-containing deep water the number of anaerobic saprophytic bacteria was comparable to that of the aerobic saprophytic bacteria. Anaerobic saprophytes were slightly more abundant than aerobic saprophytes only at 2 locations in this water mass, at 220 and $242 \mathrm{~m}$ depth. The highest anaerobic saprophyte count $(700$ anaerobic saprophytes $\mathrm{ml}^{-1}$ ) was found close to the sediment.

The water layers of special interest to us, i.e. the well-aerated surface water, the aerobic-anaerobic interface, and the near-bottom water, were investi- 
Fig. 5. Vertical distribution of aerobic and anaerobic saprophytic bacteria at 'Central' station. Left: Total profile obtained on 1 Aug 1984; right: partial profiles obtained on 6 Aug (above thermocline). 5 Aug (oxic/anoxic interphase), and 4 Aug 1984 (near-bottom water layer)

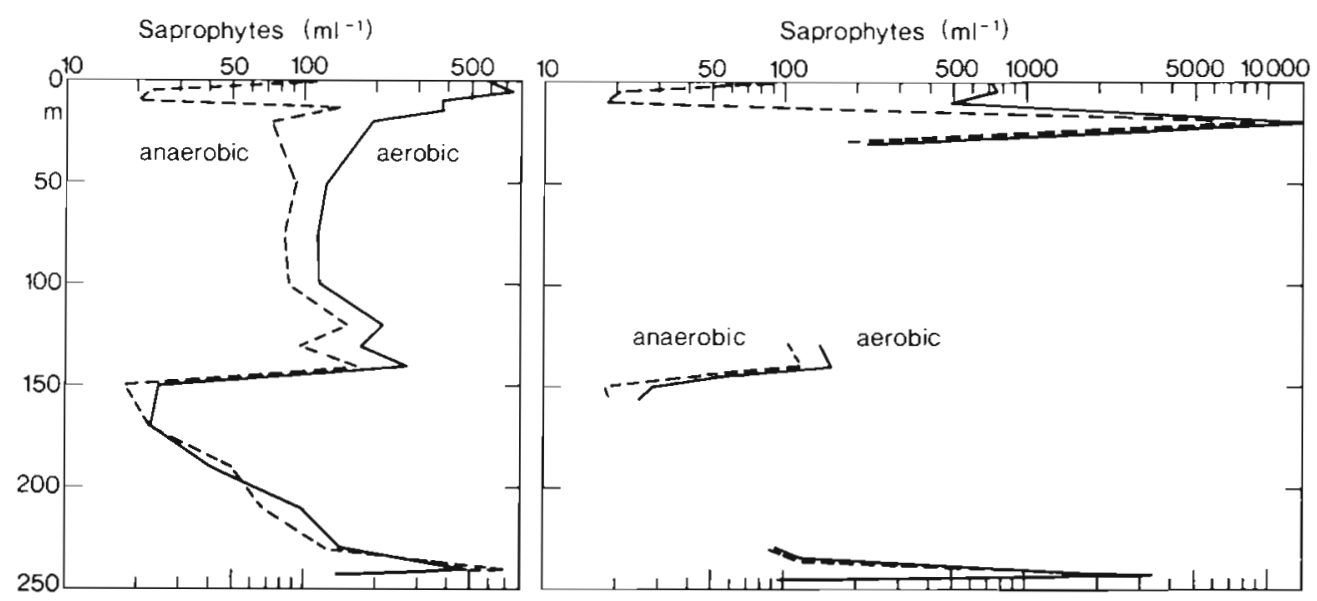

gated a few days later with the smallest vertical sampling interval possible (Fig. 5). Although the results corresponded for the most part with those for previous sampling, several differences became apparent. Thus, at the thermocline $(20 \mathrm{~m}$ depth) the aerobic and anaerobic saprophyte counts were extremely high and approximately equal $\left(14000 \mathrm{ml}^{-1}\right.$ and $11000 \mathrm{ml}^{-1}$ respectively). This, however, was an exception, since the anaerobic saprophyte counts in the euphotic zone were consistently much lower than the aerobic saprophyte counts.

At the oxic-anoxic interface, an increase in saprophyte numbers was observed, followed by a rapid decrease in the $\mathrm{H}_{2} \mathrm{~S}$-containing water. The numbers of aerobic and anaerobic saprophytic bacteria were again similar in bottom waters, with a maximum $1 \mathrm{~m}$ above the sediment.

\section{Sulphate-reducing bacteria}

Sulphate-reducing bacteria were found within the entire water column (Fig. 6). Low numbers were observed in $\mathrm{O}_{2}$-rich water $\left(0.5 \times 10^{3} \mathrm{l}^{-1}\right)$. They were found in greater numbers in the anoxic waters below the $\mathrm{O}_{2} / \mathrm{H}_{2} \mathrm{~S}$ interface $\left(2.8 \times 10^{3} \mathrm{l}^{-1}\right)$, and in very high numbers in the bottom water (up to $5.5 \times 10^{3} \mathrm{l}^{-1}$ ). Exceptions, however, existed. On 6 August the oxic surface water contained unusually high concentrations of sulphate-reducing bacteria $\left(11 \times 10^{3} 1^{-1}\right)$ at the sampling depth coinciding with the thermocline (Fig. 6).

\section{DISCUSSION}

The change in $\mathrm{O}_{2}$-concentration and especially the transition from aerobic to anaerobic conditions in the water column exert a powerful influence on the microfloral composition. Changes within the bacterial popu-

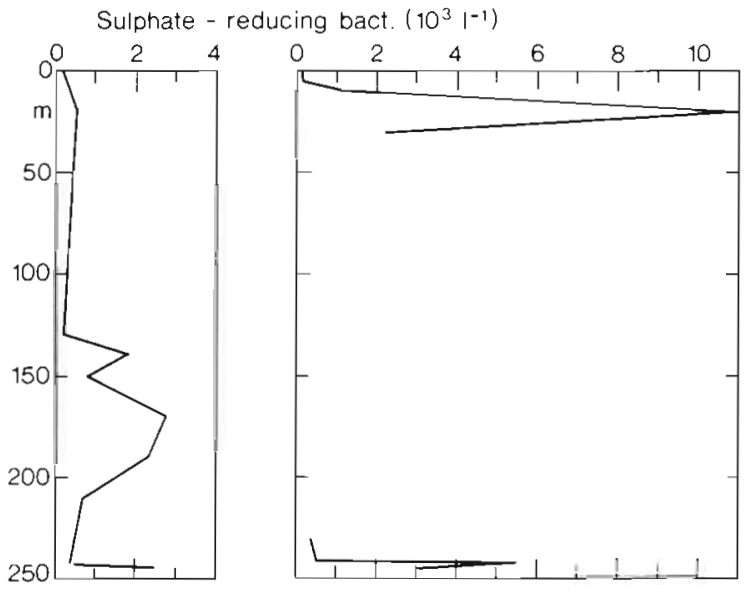

Fig. 6. Vertical distribution of sulphate-reducing bacteria measured at 'Central' station. Sampling dates as in Fig. 5

lation were observed by studying the population composition (saprophytes, sulphate-reducers) and by analysis of the size-class spectrum of the total population (Table 1).

Based on the population structure, the oxic region can be divided into 4 zones: (1) above the thermocline;

(2) within the thermocline; (3) the cold winter-water; (4) the oxic region of the $\mathrm{O}_{2} / \mathrm{H}_{2} \mathrm{~S}$ interface.

The highest values of TBN, BBM and aerobic saprophytic bacteria were found above the thermocline corresponding to the depth of the cyanobacterial maximum. The presence of high bacterial counts above the thermocline, also found by Seppänen \& Voipio (1971) in the Gotland Basin, seems to be representative of stratified water bodies (Sorokin 1964, Indrebø et al. 1979, Rheinheimer 1984). The majority of the bacteria were of the smaller size classes, with a mean cell size of $0.08 \mu \mathrm{m}^{3}$, the equivalent of $8 \times 10^{-9} \mu \mathrm{g} C$ per bacterial cell. This value is higher than the average value found by Gocke \& Hoppe (1982) of $3.5 \times 10^{-9} \mu \mathrm{g} C$ per bacteria cell in the western and central Baltic Sea. The 
Table 1. Shifts in the bacterial populations of the Gotland Basin (Hanglage station) in relation to oxic-anoxic conditions. Mean values are given in parentheses. TBN: total bacterial number; BBM: bacterial biomass; $M C V$. mean cell volume

\begin{tabular}{lccc|}
\hline Sampling location & $\mathrm{TBN}\left(\times 10^{6} \mathrm{ml}^{-1}\right)$ & $\mathrm{BBM}\left(\mu \mathrm{g} \mathrm{Cl} \mathrm{l}^{-1}\right)$ & $\mathrm{MCV}\left(\mu \mathrm{m}^{3}\right)$ \\
\hline Oxic & $5.1-5.2(5.2)$ & $33-48(41)$ & $0.06-0.09(0.08)$ \\
above thermocline & - & - & - \\
within thermocline & $0.2-0.5(0.4)$ & $3-5(4)$ & 0.12 \\
below thermocline & 0.3 & $34-39(36)$ & 0.19 \\
Oxic-anoxic interface & $1.1-1.4(1.3)$ & $0.28-0.31(0.30)$ \\
Anoxic deep water & & & \\
\hline
\end{tabular}

hydrographical conditions prevalent at the time of our study in the Gotland Basin (stable, calm weather; high water temperatures; pronounced thermocline; high primary production) may account for this discrepancy.

The ratio 0.08 between the number of anaerobic and aerobic saprophytic bacteria above the thermocline is very low. A bacterial population appears to be present here which is especially well adapted to the higher oxygen supply and more capable of oxic rather than anoxic metabolism.

An interesting phenomenon was observed on 6 August 1984 from the sample taken at $20 \mathrm{~m}$, the depth corresponding to the thermocline. Despite the presence of a high $\mathrm{O}_{2}$-concentration, coexistent with a high number of aerobic saprophytic bacteria a maximum for anaerobic saprophytic bacteria and sulphatereducers was found. The high anaerobic/aerobic saprophyte ratio ( 0.81 compared with 0.08 only $6 \mathrm{~d}$ before) shows a change within the saprophyte population. Anaerobic metabolism apparently played here an important role. The occurrence of anaerobic processes in detritus particles within oxic water was discussed recently by Alldredge \& Cohen (1987) and Sieburth (1987). Jørgensen (1977) demonstrated through laboratory experiments that bacterial sulphate reduction occurs within detritus particles in oxidized sediments as well as oxic seawater, parallel with an increase in the number of sulphate-reducers.

These findings suggest that the existence of anoxic microenvironments near the Gotland Basin thermocline was responsible for the high numbers of anaerobic bacteria. Sinking 'ageing' cyanobacterial agglomerates, which occurred in very high numbers during the period of the study, apparently represented these micro-biotopes with extremely high bacterial activity and reproduction rates (Horstmann 1975, Hoppe 1981). One Nodularia agglomerate of $1 \mathrm{~cm}$ length and $0.5 \mathrm{~cm}$ diameter can be colonized by approximately $7.5 \times 10^{8}$ bacteria, as demonstrated by Hoppe (1981). Both very large numbers of attached bacteria and countless flagellates, ciliates and rotatorians occur in these cyanobacterial agglomerates and
Contribute to the $\mathrm{O}_{2}$-consumption (Bursa 1968, Gast 1985).

Low bacterial counts and low bacterial biomass were found in the cold winter-water. Marked reductions in total bacterial numbers below the thermocline have been reported not only for the Gotland Basin (Seppänen \& Voipio 1971), but also for the Bornholm and Danzig Basins (Gocke 1977) and the Faro Basin (Rheinheimer 1984).

A distinct increase in aerobic and anaerobic saprophyte numbers occurred at the $\mathrm{O}_{2} / \mathrm{H}_{2} \mathrm{~S}$ interface. This saprophyte maximum coincided with a peak in the maximum uptake velocity of organic solutes (Gocke unpubl.), a significant decrease in nitrate, and an increase in ammonia. Rönner \& Sörensson (1985) demonstrated denitrification in the deep low oxygen waters of the Baltic proper' using as indicators the nitrate consumption, the $\mathrm{NO}_{2}$ and $\mathrm{N}_{2} \mathrm{O}$ maxima, and $\mathrm{N}_{2}$-saturation. During their investigations, an active denitrification zone occurred at a depth of ca $100 \mathrm{~m}$ where the $\mathrm{O}_{2}$-concentration was less than $0.2 \mathrm{ml} \mathrm{l}^{-1}$. Even though, in the present study, the decrease in nitrate was observed at relatively high $\mathrm{O}_{2}$-concentrations $\left(1 \mathrm{ml} \mathrm{l} \mathrm{l}^{-1}\right.$ at $130 \mathrm{~m}$ ) in the Gotland Basin, this was probably due to denitrification processes. Thus, at least part of the saprophyte population probably consists of denitrifiers. Tuttle \& Jannasch (1973) isolated

Table 2. Ratio between anaerobic and aerobic saprophytic bacteria $(R)$ and number of sulphate-reducing bacteria in the Gotland Basin ('Central' station)

\begin{tabular}{|lcc|}
\hline Sampling location & \multicolumn{1}{c}{$R$} & $\begin{array}{c}\mathrm{SO}_{4}^{2-} \text {-reducers } \\
\left(\times 10^{3} \mathrm{I}^{-1}\right)\end{array}$ \\
\hline $\begin{array}{c}\text { Oxic } \\
\text { above thermocline }\end{array}$ & $0.03-0.12(0.08)$ & $0-1.1(0.3)$ \\
within thermocline & 0.81 & 11.0 \\
below thermocline & $0.37-0.75(0.60)$ & $0-2.2(0.5)$ \\
Oxic-anoxic interface & $0.62-0.83(0.71)$ & $0.8-1.8(1.3)$ \\
Anoxic deep water & $0.85-1.50(1.10)$ & $0.4-5.4(1.7)$ \\
\hline
\end{tabular}


saprophytic bacteria in and directly above the $\mathrm{O}_{2} / \mathrm{H}_{2} \mathrm{~S}$ interface in the Cariaco Trench. They determined that these strains can also grow anaerobically with $\mathrm{NO}_{3}^{-}$.

The shift within the bacterial size-class spectrum was first apparent at the oxic-anoxic interface, where a slight increase in total bacterial number was coupled with a relatively high bacterial biomass increase. Average cell volume at the $\mathrm{O}_{2} / \mathrm{H}_{2} \mathrm{~S}$ interface was roughly double that in the oxic water above (Table 1). Saprophyte numbers fell off rapidly, whereas the numbers of sulphate-reducing bacteria increased (Table 2).

The bacterial population in the anoxic bottom water differed in many aspects from the microflora in the oxic water layer below the thermocline (Table 1). TBN in the anoxic water increased to more than $1 \times 10^{6} \mathrm{ml}^{-1}$, and BBM reached values of more than $30 \mu \mathrm{g} \mathrm{l}^{-1}$. The average cell volume was triple that of oxic waters. The shift in the size-class spectrum towards larger cell forms, beginning at the interface between oxic and anoxic waters, can be explained in either of 2 ways: (1) the existing bacterial population reacted to the change from oxic to anoxic conditions by increasing its cell sizes; (2) the bacteria population changed in favor of species more adapted to anoxic conditions. With respect to the first possibility, Sorokin (1964) made an interesting observation when studying water samples from the $\mathrm{O}_{2} / \mathrm{H}_{2} \mathrm{~S}$ boundary layer in the Black Sea: 'When counting bacteria on filters, we observed chains consisting of thiobacilli cells. The mean volume of a single bacterial cell was $0.28 \mu^{3}$ in the oxygen zone and $0.47 \mathrm{\mu m}^{3}$ in the $\mathrm{H}_{2} \mathrm{~S}$ zone'. Obviously, a bacterial species increased its cell volume in response to anoxic conditions. In the present investigation, individual species could not be examined. Such a species-specific size increase, however, probably plays a minor role in the Gotland Basin. With respect to the second possibility, natural benthic and planktonic bacterial populations react to nutrient changes with changes in the composition of the population. A change in the bacterial size-class spectrum takes place (Krambeck \& Krambeck 1981, Meyer-Reil 1983, Krambeck 1984). Krambeck (1984) classifies bacteria into 2 groups: those adapted to the existing substrate and grow actively, and those in 'stand-by position', with a smaller cell size. The latter increase in volume and number when suitable conditions occur. The anaerobic bacteria in the oxic layer of the Gotland Basin could then be classified as in 'stand-by position'. They become active and increase their cell size when exposed to anoxic conditions.

Within the population of saprophytic bacteria, anaerobic bacteria increased in anoxic water. This was shown by a high anaerobic/aerobic saprophyte ratio of 1.01. In addition, obligate anaerobic sulphate-reducers became important in anoxic deep water, where they reached maxima in its upper layers and directly above the sediment. Such a distribution pattern of sulphatereducing bacteria has been observed for other anoxic water bodies, e.g. the Black Sea (Sorokin 1964, Jannasch et al. 1974), and a shallow estuary in western Norway (Indrebo et al. 1979).

The numbers of sulphate-reducers in the anoxic water of the Gotland Basin were usually low 10.4 to $5.4 \times 10^{3} \mathrm{l}^{-1}$ ). Their contribution to TBN was only 5 to $20 \times 10^{-5} \%$. This may, however, be an underestimate. Use of a lactate-rich culture medium (see 'Materials and Methods') allowed only bacteria of the genera Desulfovibrio, Desulfotomaculum and Desulfomonas to grow (Trüper et al. 1969, Pfennig et al. 1981). Many of the recently discovered sulphate-reducing genera, such as Desulfobacter, Desulfococcus, Desulfonema, Desulfosarcina, Desulforomonas and Desulfobulbus can flourish only on special nutrient media (Widdel \& Pfennig 1977, Pfennig et al. 1981, Widdel \& Pfennig 1982). Numbers of sulphate-reducing bacteria from coastal marine sediments cultured on a lactate medium are proportional to the measured sulphate reduction rates (Jørgensen 1978). The absolute numbers, however, appear to be at least 1000-fold too low, when calculated according to Jørgensen (1978). Laanbroek \& Pfennig (1981) showed that the vertical distribution in marine sediments is the same for acetate-, propionate-, and lactate-oxidizing sulphate-reducers. It follows that observing only the lactate-oxidizing sulphate-reducers provides at least an indication of the relative distribution of microbial sulphate reduction.

These investigations in the Gotland Basin have demonstrated that a change in the bacterial population occurs with the transition from oxic to anoxic conditions. Thus facultative and obligately anaerobic bacteria replace aerobic forms in anoxic bottom water.

Acknowledgements. We thank Dr F. Pollehne for supplying data on oxygen, hydrogen sulphide and nutrients. Dr R. Hobrecht kindly supplied the anaerobic strain Clostridium sporogenes. We are also grateful to Mrs B. von Brevern and Mrs R. Koppe for their skillful technical assistance. This study was supported by grant No. MFU 0528/6 from the 'Bundesministerium für Forschung und Technologie', Bonn, FRG.

\section{LITERATURE CITED}

Alldredge, A. L., Cohen, Y. (1987). Can microscale chemical patches persist in the sea? Microelectrode study of marine snow, fecal pellets. Science 235: 689-691

Bansemir, K. Rheinheimer, G. (1970). Bakterielle Sulfatreduktion und Schwefeloxidation. Kieler Meeresforsch. 26: $170-173$

Bansemir, K., Rheinheimer, G. (1974). Bakteriologische Untersuchungen über die Bildung von Schwefelwasserstoff in einer Vertiefung der inneren Kieler Förde. Kieler Meeresforsch. 30: 91-98 
Bursa, A. S. (1968). Epicenoses on Nodularia spumigena Mertens in the Baltic Sea. Acta Hydrobiol. 10: 267-297

Ehrhardt, M., Wenck, A. (1984). Wind pattern and hydrogen sulfide in shallow waters of the Western Baltic Sea, a cause and effect relationship? Meeresforsch. 30:101-110

Fonselius, S. (1976). Determination of hydrogen sulfide. In Grasshoff, K. (ed.) Methods of seawater analysis. Verlag Chemie, Weinheim, New York, p. 71-77

Fonselius, S. (1981). Oxygen and hydrogen sulfide conditions in the Baltic Sea. Mar. Pollut. Bull. 12: 187-194

Gast, V (1985). Bacteria as a food source for microzooplankton in the Schlei Fjord and Baltic Sea with special reference to ciliates. Mar. Ecol. Prog. Ser. 22: 107-120

Gocke, K. (1977). Untersuchungen über die heterotrophe Aktivität in der zentralen Ostsee. Mar. Biol. 40: 87-94

Gocke, K., Hoppe, H.-G. (1982). Regionalverteilung der Bakterienzahl und -aktivität in der mittleren Ostsee. Botanica mar. 25: 381-389

Grasshoff, K. (1964). Zur Bestimmung von Nitrat in Meer- und Trinkwasser Kieler Meeresforsch. 20: 5-11

Grasshoff, K. (1968). Über eine empfindliche und direkte Methode zur automatischen und manuellen Bestimmung von Ammoniak im Meerwasser. Z. analyt. Chemie 234: $13-22$

Grasshoff, K. (1976). Determination of oxygen. In: Grasshoff K. (ed.) Methods of seawater analysis. Verlag Chemie Weinheim, New York, p. 59-70

Hoppe, H.-G. (1981). Blue-green algae agglomeration in surface water: a microbiotope of high bacterial activity. Kieler Meeresforsch. Sonderh. 5: 291-303

Horstmann, U. (1975). Eutrophication and mass production of blue-green algae in the Baltic. Merentutkimuslait. Julk./ Havsforskninginst. 239: 83-90

Indrebø, G., Pengerud, B., Dundas, I. (1979). Microbial activities in a permanently stratified estuary. II. Microbial activities at the oxic-anoxic interface. Mar Biol. 51 305-309

Jannasch, H. W., Trüper, H. G., Tuttle, J. H. (1974). Microbial sulfur cycle in the Black Sea. Black Sea Geol. Chem. Biol Mem. 20: 419-425

Jørgensen, B. B. (1977). Bacterial sulphate reduction within reduced microniches of oxidized marine sediments. Mar Biol. 41: 7-17

Jørgensen, B. B. (1978). A comparison of methods for the quantification of bacterial sulphate reduction in coastal marine sediments. III. Estimation from chemical and bacteriological field data. Geomicrobiol. J. 1: 49-64

Jørgensen, B. B. (1982). Ecology of the bacteria of the sulfur cycle with special reference to anoxic-oxic interface environments. Phil. Trans. R. Soc. Lond. B 298: 543-561

Krambeck, C. (1984). Diurnal response of microbial activity and biomass in aquatic ecosystems. In: Klug, $R$. (ed.) Current perspectives in microbial ecology. ASM Washington, p. 502-508
Krambeck, C., Krambeck, H.-J. (1981). Microcomputer-assisted biomass determination of plankton bacteria on scanning electron micrographs. Environ. Microbiol. 42: 142-149

Laanbroek, H. J., Pfennig, N. (1981). Oxidation of short fatty acids by sulphate-reducing bacteria in freshwater and marine sediments. Arch. Microbiol. 128: 330-335

Meyer-Reil, L.-A. (1983). Benthic response to sedimentation events during autumn to spring at a shallow water station in the Western Kiel Bight. II. Analysis of benthic bacterial populations. Mar. Biol 77: 247-256

Pfennig, N., Widdel, F., Trüper, H. G. (1981). The dissimilatory sulphate-reducing bacteria. In: Starr, M. P., Stolp, H., Trüper, H. G., Balows, A., Schlegel, H. G. (eds.) The procaryotes. A handbook on habitats, isolation and identification of bacteria. Springer Verlag, Berlin, Heidelberg, New York, p. 926-940

Rheinheimer, G. (1984). Review. Bacterial ecology of the North and Baltic Seas. Botanica mar. 27: 277-299

Rönner, U., Sörensson, F. (1985). Denitrification rates in the low-oxygen waters of the stratified Baltic Proper. Appl. environ. Microbiol. 50: 801-806

Schneider, J. (1977). Desulfurication and sulfur oxydation. In Rheinheimer, G. (ed.) Microbial ecology of a brackish water environment. Springer Verlag, Berlin, Heidelberg, New York, p. 244-248

Seppänen, H. Voipio, A. (1971). Some bacteriological observations made in the northern Baltic. Merentutkimuslait. Julk./Havsforskningsinst. 233: 43-48

Sieburth, J. McN. (1987). Contrary habitats for redox-specific processes: methanogenesis in oxic waters and oxidation in anoxic waters. In: Sleigh, M. A. (ed.) Microbes in the sea. Ellis Horwood LTD Publishers, Chichester, p. 11-38

Sorokin, Yu. I. (1964). On the primary production and bacterial activities in the Black Sea. J. Cons. Int. Explor. Mer 29: $41-60$

Trüper, H. G., Kelleher, J. J., Jannasch, H. W. (1969). Isolation and characterization of sulphate-reducing bacteria from various marine environments. Arch. Microbiol. 65 . 208-217

Tuttle, J. H., Jannasch, H. W. (1973). Sulfide and thiosulphateoxidizing bacteria in anoxic marine basins. Mar. Biol. 20: $64-70$

Widdel, F, Pfennig, N. (1977). A new anaerobic, sporing, acetate-oxidizing, sulphate-reducing bacterium, Desulfotomaculum (emend) acetoxidans. Arch. Microbiol. 112: $119-122$

Widdel, F., Pfennig, N. (1982). Studies on dissimilatory sulphate-reducing bacteria that decompose fatty acids. II. Incomplete oxidation of propionate by Desulfobulbus propionicus gen. nov., sp. nov. Arch. Microbiol. 131. 360-365

Zimmermann, R., Iturriaga, R., Becker-Birck, J. (1978). Simultaneous determination of the total number of aquatic bacteria and the number thereof involved in respiration. Appl. environ. Microbiol. 36: 926-935 